\title{
Azoto dujos padangose. Jụ įtaka transporto priemonių eksploataciniam saugumui ir ekonomiškumui
}

\author{
Saulius Grinkevičius, Sigutė Ežerskienė* \\ Klaipedos valstybinè kolegija, Technologiju fakultetas \\ Bijūnu g. 10, LT-91123 Klaipeda \\ el.paštas: s.grinkevicius@kvk.lt, s.ezerskiene@kvk.lt
}

(Gauta 2021 m. kovo mèn.; atiduota spaudai 2021 m. balandžio mèn.; prieiga internete nuo 2021 m. gegužès 11 d.)

\begin{abstract}
Anotacija
Eksploatuojant keleivines transporto priemones degalų suvartojimo ekonomiškumas siejamas su tuo, kaip yra valdoma transporto priemonè. Ekonomiškas transporto priemonès valdymas priklauso nuo variklio, transmisijos, aerodinaminio pasipriešinimo bei transporto priemonès riedejjimo. Variklio, transmisijos ir aerodinaminiai nuostoliai paprastai yra siejami su šių transporto priemonės dalių konstrukcija, o riedėjimo nuostoliai yra susiję su transporto priemonės padangomis ir tai yra vienintelè transporto priemonės dalis, turinti tiesioginị sąlytị su keliu. Pripūstų padangų pasipriešinimas riedèjimui yra svarbus atsparumo komponentas, lemiantis transporto priemonès judèjimą ir prisidedantis prie transporto priemonès degalų sąnaudų sumažejimo. Daugelis tiriamųjų darbų buvo sutelkta ị tai, kaip ịvairūs padangų parametrai (pvz., apkrova, dujų slègis padangoje ir transporto priemonès judejjimo greitis) lemia pasipriešinimą riedèjimui ir degalų sąnaudų ekonomiškumą. Naujausi tyrimai rodo, kad padangos, pripūstos azoto dujų, gali palaikyti tinkamą slėgị ir sumažinti gumos susidèvėjimą. Todėl šio tyrimo tikslas yra ištirti azoto dujomis pripūstų padangų naudojimo įtaką transporto priemonès saugumui, eksploatacinių savybių pagerinimui ir eksploatacinių išlaidų sumažinimui.
\end{abstract}

Reikšminiai žodžiai: lengvasis automobilis, pneumatinè padanga, azotas, azoto dujos.

\section{Abstract}

In the operation of passenger vehicles, fuel economy is linked to the way the vehicle is operated. Economical control of the vehicle depends on the engine, transmission, aerodynamic resistance and rolling of the vehicle. Engine, transmission, and aerodynamic losses are usually associated with the construction of these vehicle parts, while rolling losses are related to the vehicle tires and are the only vehicle part in direct contact with the road. The rolling resistance of inflated tires is an important component of the resistance that affects the movement of the vehicle and contributes to the fuel consumption of the vehicle. Much of the research has focused on how various tire parameters (e.g., load, inflation pressure, and speed) affect rolling resistance to increase fuel economy. Recent researches show that tires inflated with nitrogen gas can maintain proper pressure and reduce rubber wear. Therefore, the purpose of this study is to investigate the impact of the use of nitrogen-inflated tires on vehicle safety, performance improvement and reduction of operating costs.

Key words: Passenger car, pneumatic tire, nitrogen, nitrogen gas

\section{Ivadas}

Pneumatinès padangos neatsiejamos nuo transporto priemonių konstrukcijos. Nuo jų eksploatacijos priklauso transporto priemonių, keleivių ir krovinių saugumas. Šiuolaikinis keliu transportas naudoja pneumatines padangas, tačiau galima pastebėti ir kitokių tendencijų padangų gamybos ir kūrimo technologijose. Nepaisant kai kurių naujovių, lengvasis transportas eksploatuojamas naudojant pneumatines padangas. Siekiant padidinti padangos ilgaamžiškumą, patikimumą ir tokiu būdu užtikrinti transporto priemonių saugų eksploatavimą, padangos pripildomos ne suspausto oro, o azoto dujų, kurios, kaip rodo jų cheminè sudètis, neturi vandens ir kitokių cheminių elementų, kurie turètų įtakos spartesniam padangų dèvèjimuisi eksploatuojant transporto priemones. Pasinaudojant tam tikromis priemonėmis ir literatūros šaltiniais atliekamas pneumatinių padangų, pripildytų oro ir azoto dujomis, tyrimas. 
Tyrimo tikslas - ištirti azoto dujomis pripūstų padangų naudojimo ịtaką transporto priemonès saugumui, eksploatacinių savybių pagerinimui ir eksploatacinių išlaidų sumažinimui.

\section{Uždaviniai:}

1. Išnagrinèti azoto dujų chemines savybes ir naudojimo sritis.

2. Išnagrinèti pneumatinių padangų, pripildytų azoto dujomis, savybes.

3. Išnagrinèti slègio pokyčio ịtaką pneumatinei padangai.

4. Išanalizuoti padangų, pripildytų azoto dujomis, įtaką transporto priemonių saugiam eksploatavimui.

\section{Tyrimo rezultatai}

Azoto naudojimo privalumai. Azotas yra sausos ir inertiškos dujos, kurios buvo naudojamos orlaivių, lenktyninių automobilių, karinių transporto priemonių ir visureigių padangų pripūtimui. Azotas padeda išlaikyti padangų pripūtimo slègi ilgiau ir padidinti degalų naudojimo efektyvumą (Hannifin, 2007). Palyginti su azotu, deguonis suslègtame ore persismelkia per padangos sieną daug greičiau, taip sumažindamas padangų pripūtimo slègị. Orą sudaro ir vandens molekulès, kurios linkusios reaguoti ị padangą ir sukelia ratlankio koroziją. Sausas azotas gali išlaikyti tinkamą pripūtimo slègi, tokiu būdu padangos atvėsinamos ir taip yra sumažinamas pasipriešinimas riedejjimui ir išvengiama perkrovos. Deguonies pralaidumo koeficientai yra aukštesni nei azoto rodikliai visose tirtose gumos medžiagose, įskaitant ir tas, iš kurių gaminamos padangos (Parkash, 2007). Deguonies pralaidumo koeficientų santykis, padalytas iš azoto koeficientų, yra nuo 3 iki 4, priklausomai nuo konkrečios gumos. Tai reiškia, kad deguonis prasiskverbia nuo 3 iki 4 kartu greičiau per gumą nei azoto molekulès. Azoto molekulių dydis yra didesnis nei deguonies, nepaisant to, kad azoto molekulinè masè $(28 \mathrm{~g} / \mathrm{mol})$ yra mažesnè už molekulinę deguonies masę (32 $\mathrm{g} / \mathrm{mol}$ ), vadinasi, deguonis yra didesnis nei azotas. Be to, vanduo, esantis ore, gali pakeisti skysčio pavidalą $\mathfrak{i}$ garus esant atitinkamai temperatūrai. Esant aukštesniam darbinès temperatūros slègiui padangose pripūstas oras gali padidèti nuo 0,26 Psi esant $600 \mathrm{~F}$ iki 2,89 PSI esant $1400 \mathrm{~F}$ (Daws, 2010).

Laikui bėgant padangos suyra, nes deguonis judėdamas padangos paviršiumi oksiduoja gumos junginius, dèl šių reakcijų pablogèja gumos savybès. Pripūtus padangas azotu žymiai sumažinamas padangų susidèvèjimas. Azotas yra inertinès dujos, kuris neturi ịtakos ratlankių korozijai ir sumažina oro temperatūrą padangoje jos eksploatavimo metu (Hannifin, 2007). 1 paveiksle parodytas deguonies ir azoto molekulių pralaidumas per padangą.

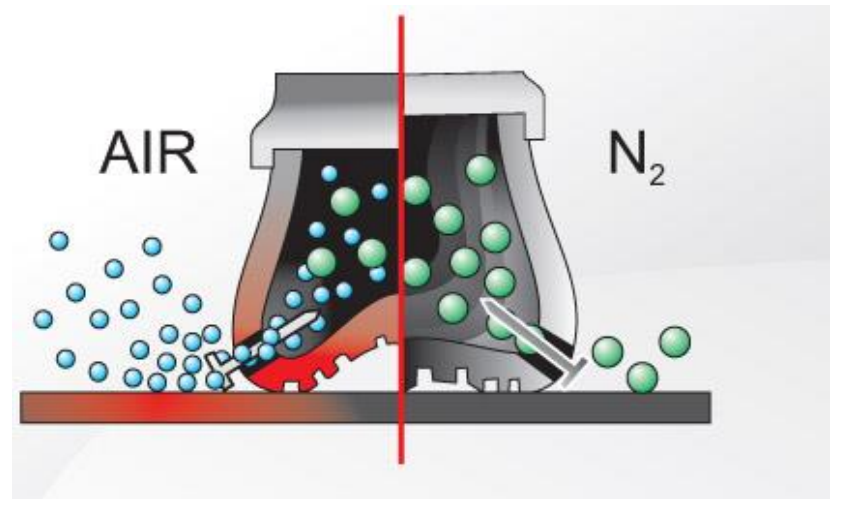

1 pav. Deguonies ir azoto molekulių pralaidumas per padangą (Prakash, 2007)

Fig. 1. Permeability of oxygen and nitrogen molecules through a tire (Prakash, 2007) 
Azoto dujų naudojimo padangose privalumai: geresnis padangų eksploatavimo laikas, degalų naudojimo efektyvumo didinimas, didesnis transporto priemonès saugumas ir mažesnès eksploatavimo sąnaudos (Parkash, 2007).

Azoto dujų parametria. Azotas - cheminis elementas, Mendelejevo cheminių elementų lentelëje pažymètas raide $\mathbf{N}$ (lot. Nitrogenium), apibūdinamas, kaip gyvybės nepalaikančios dujos ir sudètinè aplinkos oro dalis. Oras, kuriuo kvėpuojame, sudarytas iš $78 \%$ azoto, $21 \%$ deguonies, ir likęs $1 \%$ (2 pav.) - kitos cheminès medžiagos.

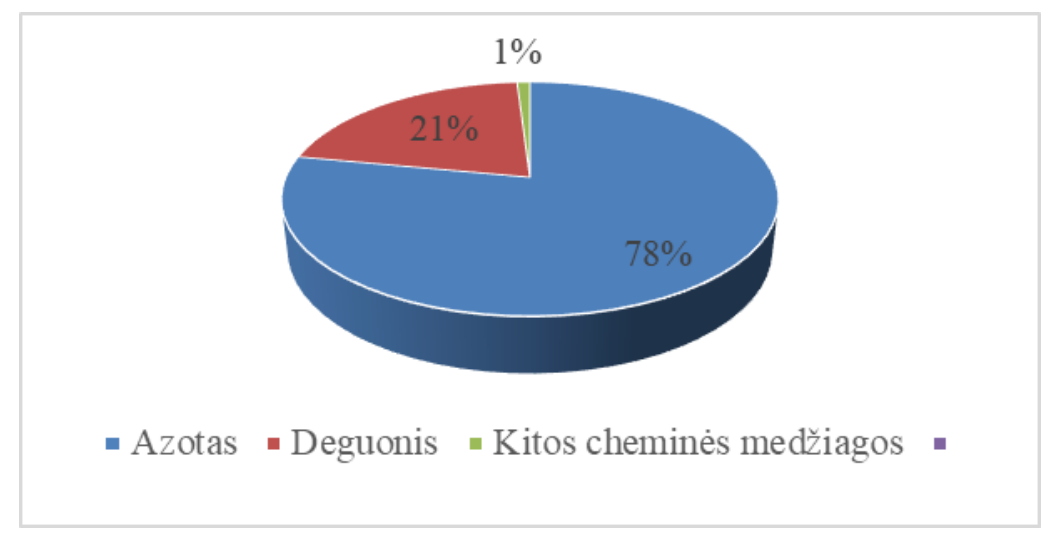

2 pav. $\mathrm{O}_{2}$ cheminè sudètis

Fig. 2. Chemical composition of $\mathrm{O}_{2}$

Azoto cheminès savybès ( 3 pav.): azoto dujos bespalvès, bekvapès, mažai tirpios vandenyje, skystoje būsenoje virimo temperatūra $\left(-196^{\circ} \mathrm{C}\right)$

\begin{tabular}{|l|l|}
\hline Kritinè temperatūra & $126,25 \mathrm{~K}$ \\
\hline Kritinis slègis & $3,905 \mathrm{MPa}$ \\
\hline Kritinis tankis & $0,304 \mathrm{~g} / \mathrm{cm}^{3}$ \\
\hline Dielektrinè skvarba & $1,000528 \times 10^{25}$ \\
\hline Atstumas tarp atomų molekulèje & $0,10976 \mathrm{~nm}$ \\
\hline
\end{tabular}

3 pav. Azoto dujų parametria (Prakash, 2007)

Fig. 3. Nitrogen gas parameters (Prakash, 2007)

Temperatūros poveikis azoto dujoms minimalus, todèl azotas naudojamas įvairiose chemijos pramonès, maisto pramonès, medicinos, transporto srityse. Transporto srityje azotas naudojamas pneumatinèse padangose, siekiant sumažinti temperatūrą, atsirandančią padangos viduje intensyvaus judèjimo sąlygomis, taip pat veikiant transporto priemonès masei ir kelio nelygumams, dèl kurių atsiranda padangos deformacija, molekulinė trintis, sukelianti temperatūros pokyčius.

Azotas taip pat pasižymi antioksidacinėmis savybėmis, stabdančiomis įvairius korozijos ir oksidacijos procesus. Padangose tokie procesai vyksta nuolat, kadangi su oru i padangą patenka vanduo, deguonis ir kitos cheminès medžiagos, sukeliančios metalų oksidaciją ir kitų medžiagų nepageidaujamas chemines reakcijas padangos viduje.

Azotas - stabilaus slègio garantas. Kaip teigia Karlas Vilhelmas Šelè, ,„pastovaus tūrio dujų slègis yra tiesiogiai proporcingas temperatūrai“". Taigi azoto dujos nestabilizuoja padangos, o išlieka pačios stabilios kaip dujos, o stabilumo atžvilgiu ir oras, kaip dujos, yra toks pat stabilus, kaip ir azoto dujos. Naudojant azoto dujas padangoje, slègis išlieka stabilus nepriklausomai nuo temperatūros. Šiltuoju metų laiku $\left(+30{ }^{\circ} \mathrm{C}\right.$ ir aukštesnè) esant intensyviam transporto priemonès judèjimui kelyje, padangose oro slègis kinta iki 0,3 bar., kai tuo pat metu slègis padangoje, pripildytoje azoto dujų, kinta vos 0,1 bar. Esančios dujos padangoje neužtikrina geresnio padangos 
kontakto su kelio paviršiumi, jos tik palaiko pastovų slėgi padangose, nepriklausomai nuo temperatūros svyravimų.

Oro slègis padangoje tiesiogiai lemia padangos keliamają galią arba didžiausią leistiną padangos apkrovą. Kuo žemesnis slègis, tuo mažiau kilogramų gali išlaikyti padanga ir atvirkščiai. Padangos apkrovos indeksas (nurodytas ženklu ant padangos šono) nurodo apkrovą kilogramais, esant tam tikram dujų slègiui padangoje.

Slègio padangoje sumažèjimas sumažina padangos keliamają galią. Keičiant slègi padangoje, galima padidinti padangos keliamają galią, tačiau ši procedūra nepateisinama daugumai lengvuju automobilių. Netinkamas slègis padangoje daro neigiamą poveiki padangos struktūrai, o kartu ir transporto priemonès saugiam eksploatavimui: posūkiuose;

- žemas padangos slėgis priekinèje ašyje daugeliu atvejų lemia nepakankamą valdomumą

- žemas galinių padangų slègis daugeliu atvejų lemia slydimą posūkiuose.

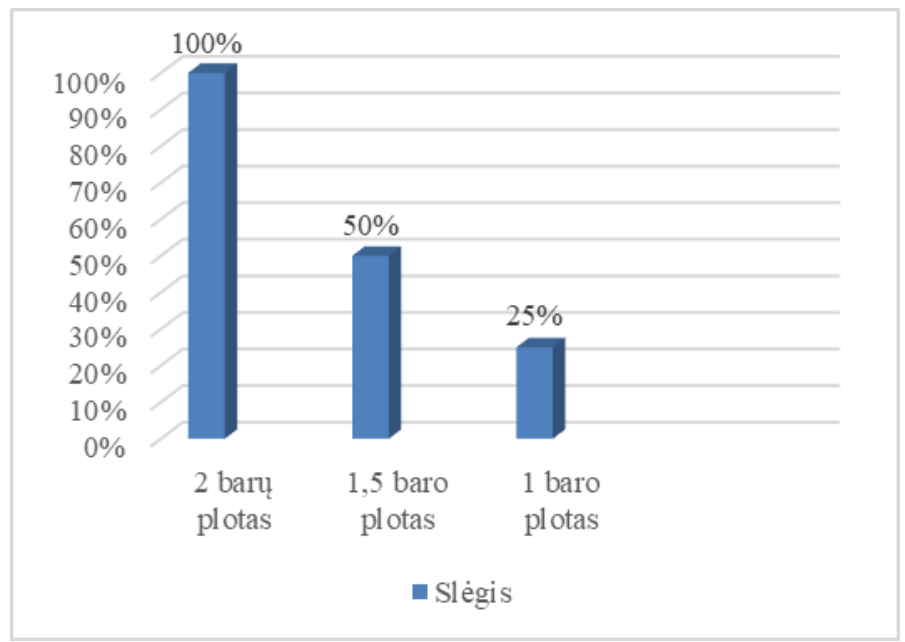

4 pav. Padangos ir kelio kontakto ploto dydis išreikštas procentais, priklausantis nuo oro slègio padangoje

Fig. 4. The size of the tire-road contact area is expressed as a percentage based on the tire pressure

Pusę kelio ir padangos kontakto ploto prarandama, kai slėgio kritimas yra 0,5 baro (4 pav.). Tinkamai pripūstoje padangoje oro slègis padeda tolygiai paskirstyti apkrovą kelio ir padangos kontakto plote ir užtikrina padangos konstrukcijos stabilumą.

Sumažinus padangų slègi $10-15 \%$, padangų nusidèvèjimo greitis padidèja $20 \%$, padanga praranda reikiamą elastingumą ir atsparumą šoninèms jẻgoms, o tai labai pablogina automobilio valdomumą ir padangų atsako ị vairuotojo veiksmus tikslumą. Padangos sąlyčio su keliu formos pakeitimas neigiamai veikia padangos atsparumą akvaplanavimui, blogina sukibimą su šlapia kelio danga.

Padidèjęs slègis taip pat turi ịtakos kelio ir padangos kontakto ploto formos pokyčiui, dèl kurio spartèja ir būdingas protektoriaus nusidèvejjimas, padangos sukibimo savybès (ypač posūkiuose), taip pat sumažejja padangos atsparumas akvaplanavimui.

Oro temperatūra tiesiogiai veikia padangų slègị. Kai aplinkos temperatūra pasikeičia $8{ }^{\circ} \mathrm{C}$, padangų slègis pasikeis apie 0,1 bar. (kils kylant temperatūrai ir kris žemèjant temperatūrai). Lietuvoje vasaros ir žiemos temperatūrų skirtumas yra maždaug $20{ }^{\circ} \mathrm{C}$, todèl, nustatant žiemos temperatūrą, slègis sumažèja maždaug 0,3 bar., atsiradęs slėgio skirtumas 0,3 bar. sukuria neigiamą poveiki transporto priemonès valdomumui, padangų susikabinimui su kelio paviršiumi ir jų dèvejjimuisi.

Azoto naudojimas padangose. Azotas naudojamas padangose yra išgryninamas ir sudaro 95-97\%, tai $20 \%$ didesnè koncentracija tūrio vienete nei mūsų ịkvepiamame ore ir ore, kuriuo 
pripildomos pneumatinès padangos. Kadangi azoto dujoms minimalų poveikị turi temperatūros svyravimai, todèl slègis padangose išlieka stabilus ịvairiomis eksploatacijos ir gamtinèmis sąlygomis.

Naudojant azoto dujas pneumatinėse padangose, sumažeja padangos sprogimo tikimybè. Padangos sprogimas, tai yra staigus padangos plyšimas važiuojant, kai dèl padangos kontakto su kelio paviršiumi padidejja pačios padangos temperatūra ir joje esančių dujų temperatūra ir slègis. Šiame kontekste padangu pripildymas azotu yra aktualus „Formulès 1“ lenktynininkams, o ne eiliniams miesto ar užmiesčio vairuotojams. Taip, iš tiesų azotas nepalaiko degimo, tačiau padangos sprogimas paprastai ìvyksta transporto priemonei judant dideliu greičiu (FORMULE் 1) arba kai ratai pervažiuoja gilią duobę ar aštrią kliūtị.

Naudojant azotą sulètèja padangos senèjimo procesas. Tai yra dèl to, kad pildant azotą padangos viduje praktiškai nèra oro, vidinè rato konstrukcija yra geriau apsaugota, taip pat vidinis, sandarinantis gumos sluoksnis išlieka ilgiau nepaveiktas senėjimo procesų, susijusių su cheminių elementų tarpusavio reakcija.

Visos anksčiau išvardintos azoto dujų savybès, lemiančios pneumatinès padangos eksploatacini ilgaamžiškumą ir patikimumą, sukuria sąlygas saugiam transporto priemonès eksploatavimui. Čia didžiausią vaidmeni atlieka azoto dujomis palaikomas pastovus slègis padangose. Esant pastoviam slègiui padanga mažiau dyla, jos dinaminis stabilumas nekinta, taip pat nekinta transporto priemonės judèjimo trajektorija ir tolygumas, stabdymo efektyvumas.

Atlikus tyrimą su realiais automobiliais, kurių padangos pripildytos azotu ir oru, esant leistinoms važiavimo sąlygoms ir įvairiomis gamtinėmis sąlygomis, fiksuojami duomenys neturèjo skirtumų tarp padangu pripildytų oru ir padangų pripildytų azotu. Normaliomis eksploatacinemis sąlygomis, padangoje, kuri pripildyta azoto dujomis ir slègis 2 bar. esant temperatūrai $+20{ }^{\circ} \mathrm{C}$, po temperatūros pokyčio iki $+10^{\circ} \mathrm{C}$, slègis padangoje liko nepakitęs -2 bar. Padangoje, kuri pripildyta oru, matavimo rezultatai išliko analogiški.

\section{Išvados}

1. Azotas turi tam tikrų technologinių pranašumų, palyginti su oru, padangų pripūtimui. Ar šie pranašumai gali būti praktiškai naudingi, priklauso nuo to, kaip naudojamas automobilis.

2. Azoto naudojimas gali būti naudingas, jei transporto priemonès valdytojas patenka ị vieną iš žemiau išvardintų kategorijų:

- $\quad$ turint vieną ar daugiau automobilių, kurie pirmiausia naudojami lenktynių trasoje;

- $\quad$ vairuojant labai taupiai ir automobilis ilgesni laiką gali būti nenaudojamas;

- turint kolekcinių automobilių, kurie retai važiuoja dideliais atstumais.

3. Jei reguliariai naudojamasi automobiliu, azoto dujų naudojimas nesuteikia jokios praktinès naudos, ypač ivvertinant jo kainą ir nepatogumus, siejamus su pripildymu.

4. Net nedidelis slègio padangose pokytis gali lemti greitesnị ir netolygų padangų nusidèvèjimą. Dèl slėgio skirtumų mažeja padangos ir asfalto kontakto plotas, didèja stabdymo atstumas, prasteja sukibimas. Sausas azotas gali išlaikyti tinkamą slègi, tokiu būdu padangos atvėsinamos ir taip yra sumažinamas pasipriešinimas riedejjimui ir išvengiama perkrovos.

5. Po atliktų tyrimų ir gautų duomenų apdorojimo, galima teigti, kad azotas bendrosios paskirties transporto priemonių pneumatinèse padangose turi tik minimalią itaką eismo saugumui, ekonomiškumui.

\section{Literatūra}

1. Anghelache, G. Negrus, E. M., Ciubotaru, O. (2013). Investigation of Shear Stresses in the Tire-Road Contact Patch. Society of Automotive Engineers, SAE 2003-01-1273, 2013. 
2. Daws, J.W. (2010). Nitrogen Inflation for Passenger Car and Light Truck Tires. Prieiga internete: https://www.branick.com/wp-content/uploads/2019/03/Dr.-John-Daws-Nitrogen-Inflation-Study.pdf

3. Hannifin P. (2007). Nitrogen Generator for Tire Inflation. Prieiga internete: http://www.parker.com/balston/OEM/cat/english/ParkerTSN2A.pdf

4. Prakash, V. (2007). Effect of Nitrogen Filling on Tire Rolling Resistance and Vehicle Fueleconomy. Prieiga internete: https://tigerprints.clemson.edu/cgi/viewcontent.cgi?article=1236\&context=all_theses

5. The Effects of Varying the Levels of Nitrogen in the Inflation Gas of Tires on Laboratory Test Performance (2009). National Highway Traffic Safety Association.

6. Nitrogen in Tyres and Road Safety (2021). Prieiga internete: https://www.arrivealive.mobi/nitrogen-in-tyresand-road-safety

\section{Nitrogen Gas in Tyres. Their Impact on Vehicle Operational Safety and Economy}

(Received in March, 2021; Accepted in April, 2021; Available Online from 11 ${ }^{\text {th }}$ of May, 2020)

\section{Summary}

The air we breathe is 78 percent nitrogen, 21 percent oxygen and the rest 1 percent other chemical substances. Nitrogen gas is non-combustible, non-flammable, non-corrosive in pure form and environmentally friendly. Nitrogen tire gas does not attack or oxidize the rubber of the tire from the inside like air does. It is a pure gas, so it does not hold heat and the tires run cooler.

Nitrogen inflation of tires has been common for tires fitted on race cars such as F1, as well as aircraft, trucks and vehicles used in mining and other industrial applications for a long time. Nitrogen gas is also used in Tour de France bike tires, in all the space shuttle tires and even the moon buggy had nitrogen in its tires.

The key benefits of using nitrogen are a slower rate of pressure loss and cooler running temperature of tires.

The molecular structure of nitrogen differs from that of air, in such a way that it escapes through the tire's inner liner or tube at a slower rate than regular compressed air.

The result is a significant slower rate of pressure loss in a tire filled with nitrogen. For example, it might take up to six months to lose $0.14 \mathrm{kpa}$ with nitrogen, compared to just one month with compressed air.

Tires inflated with nitrogen also run cooler than those inflated with air, with some significant advantages.

One such advantage is an improvement in tire life of up to $20 \%$, because by reducing the tire's running temperature, you can increase its tread life.

Improved road handling is another benefit that stems from cooler running tires.

As tires heat up, their inflation pressure increases, which then reduces the size of the tire's footprint - the area that has contact with the road - the tire then loses grip because of this smaller footprint. So the cooler they run the better the tires will grip the road. 